\title{
Perceived usefulness and perceived ease of use: antecedents of attitude towards laptop use among science and mathematics teachers in Malaysia
}

\begin{abstract}
Educational institutions are increasingly turning to Information and Communication Technologies (ICT) to promote the development of a technologically literate nation. In line with this stance, teachers are expected to use ICT tools to facilitate instruction in the classroom. This paper sought to determine the antecedents of attitude towards laptop use among the Science and Mathematics teachers in Malaysian secondary schools. Hereto, the Technology Acceptance Model served as theoretical framework and six hypotheses were put forward. An investigation was carried out among 292 Science teachers and 278 Mathematics teachers in selected schools. Perceived usefulness was shown to be a good predictor of attitude towards laptop use, whereas perceived ease of use did not directly impact teachers' attitude towards laptop use. The findings were found to be similar for both Science and Mathematics teachers
\end{abstract}

Keyword: Laptop use; Attitude; Perceived usefulness; Perceived ease of use; Technology acceptance model (TAM); Science; Mathematics; Teachers 